\title{
Antidiabetic Activity of Methanolic Extract of Artabotrys suaveolens Leaves in 3T3-L1 Cell Line
}

\author{
Surapaneni Krishna Mohan ${ }^{1 *}$ (D), Vishnu Priya Veeraraghavan² (D) Janardhana \\ Papayya Balakrishna ${ }^{3}$, Gayathri Rengasamy² ${ }^{\text {DD }}$ and S. Rajeshkumar ${ }^{4}$ (D)
}

\begin{abstract}
${ }^{1}$ Department of Biochemistry, Panimalar Medical College Hospital \& Research Institute, Varadharajapuram, Poonamallee, Chennai - 600 123, Tamil Nadu, India. ${ }^{2}$ Department of Biochemistry, Saveetha Dental College, Saveetha Institute of Medical and Technical Sciences (SIMATS), Saveetha University, 162, P.H. Road, Velappanchavadi, Chennai-600 077, Tamil Nadu, India. ${ }^{3}$ Department of Biotechnology, Stellixir Biotech Private Ltd, Peenya $2^{\text {nd }}$ Stage Industrial Area, Bangalore - 560058, Karnataka, India. ${ }^{4}$ Department of Pharmacology, Saveetha Dental College, Saveetha Institute of Medical and Technical Sciences (SIMATS), Saveetha University, 162, P.H. Road, Velappanchavadi, Chennai - 600 077, Tamil Nadu, India.
\end{abstract}

\begin{abstract}
Artabotrys suaveolens is an evergreen shrub that belongs to the Annonaceae family, traditionally known for its use in regulating menstruation and in treating cholera. Other medicinal properties of this shrub remain to be studied and validated. The current study was aimed to evaluate the anti-diabetic property of methanolic extract of Artabotrys suaveolens leaves in vitro using 3T3L1 cell line. Antidiabetic property of methanolic extract of $A$. suaveolens was evaluated in vitro by assaying for glucose uptake and the translocation of glucose transporter (GLUT4). The effect of $A$. suaveolens extract in inhibiting the activity of $\alpha$-Glucosidase and, $\alpha$-Amylase enzymes was also evaluated using colorimetric assays. The cytotoxic effect of the extract was determined using the MTT assay. A. suaveolens (AS) extract treatment enhanced glucose uptake in $77.39 \%$ of the cells, and GLUT4 expression was found in $74.87 \%$ of the cells treated with AS extract. The extract inhibited $\alpha$-amylase activity by $70.29 \%$ and $\alpha$-glucosidase activity by $74.06 \%$. MTT assay showed that, AS extract had no cytotoxic effect on 3T3-L1. Our results attribute a promising anti-diabetic property for the methanolic extract of $A$. suaveolens leaves. Further studies that elucidate the molecular mechanism behind the anti-diabetic property of the extract must be carried out to recommend this as a possible alternative treatment for diabetes.
\end{abstract}

Keywords: Artabotrys suaveolens, Anti-diabetic, 3T3-L1, MTT assay, GLUT4, $\alpha$ - glucosidase, Diabetes mellitus

*Correspondence: krishnamohan.surapaneni@gmail.com; +91-9789099989

(Received: September 20, 2019; accepted: March 05, 2020)

Abbreviations: AS - Artabotrys suaveolens; DMSO: Dimethyl sulfoxide; DMEM: Dulbecco's Modified Eagle's medium; FBS: Fetal Bovine Serum; FITC: Fluorescein isothiocyanate. D-PBS: Delbucco's Phosphate Buffered Saline; FACS: Fluorescent Activated Cell Sorter, GLUT4:Glucose transporter 4; PNPG - p-nitrophenyl- $\alpha$-dglucopyranoside; MTT: 3-(4,5-dimethylthiazol-2-yl)-2,5diphenyltetrazolium bromide; 2-NBDG: 2-(N-(7-nitrobenz-2-oxa-1,3-diazol-4-yl)amino)-2-deoxyglucose; WHO-World Health Organization; $\mu \mathrm{g}$ : Micrograms; $\mathrm{mL}$ : millilitre; SD: Standard Deviation.

Citation: Surapaneni Krishna Mohan, Vishnu Priya Veeraraghavan, Janardhana Papayya Balakrishna, Gayathri Rengasamy, S. Rajeshkumar, Antidiabetic Activity of Methanolic Extract of Artabotrys suaveolens Leaves in 3T3-L1 Cell Line, J. Pure Appl. Microbiol., 2020; 14(1):573-580. https://doi.org/10.22207/JPAM.14.1.59

(C) The Author(s) 2020. Open Access. This article is distributed under the terms of the Creative Commons Attribution 4.0 International License which permits unrestricted use, sharing, distribution, and reproduction in any medium, provided you give appropriate credit to the original author(s) and the source, provide a link to the Creative Commons license, and indicate if changes were made. 


\section{INTRODUCTION}

Artabotrys suaveolens is an evergreen shrub that belongs to the Annonaceae family, traditionally known for its use in regulating menstruation and in treating cholera. The genus Artabotrys consists of 2,200 species ${ }^{1,2}$ and is geographically distributed in tropical and subtropical regions of East Asia and Africa ${ }^{2,3}$. The roots and bark of Artabotrys have long been used as emmenagogue, and to relieve weakness after childbirth ${ }^{4,5}$. The leaves of Artabotrys have also been used in traditional medicine. However, the anti-diabetic properties of Artabotrys suaveolens remain unexplored.

Diabetes mellitus (DM), an endocrine disorder characterized by impaired secretion and/or function of insulin that results in blood glucose levels high and perturbations in protein carbohydrate, and lipid metabolism ${ }^{6}$, will affect an estimated at 300 million by the year $2025^{7,8}$. DM results in several complications, including cardiovascular diseases, renal failure, and bone related diseases ${ }^{9}$. Several strategies have been employed to treat Diabetes to maintain normal blood sugar levels. Inhibiting sugar metabolizing enzymes have been a vital approach ${ }^{10}$. There are synthetic drugs that work with this approach, but their adverse warrant the use of natural antidiabetic compounds ${ }^{11}$. Numerus enzyme changes that are directly related to diabetes mellitus focuses on the preliminary problem during the course of the disease. DM can be described as the disease with protean menifestations, includes coronary sclerosis, coronary artery disease, idiopathies, and renal, retinal and neurologic disorders. Patients diagnosed with premature arterial disease exhibits signs of preclinical or subclinical diabetes treated for fasted blood sugar level or the tolerance of glucose.

In this study, we evaluated the antidiabetic activity of the methanolic extract of Artabotrys suaveolens leaves using biochemical and cellular assays. We assayed for the inhibitory effect of the extract on the activity $\alpha$-glucosidase and $\alpha$-amylase enzymes. We also analysed the cellular glucose uptake and GLUT4 expression levels and analysed the cytotoxic effects of the plant extract on 3T3-L1 cells.

\section{MATERIALS AND METHODS}

Chemicals and reagents

DMEM High Glucose (\#AL219A, Himedia), DMEM without glucose (\#AL186, Himedia), Fetal Bovine Serum (\#RM10432,Himedia), D-PBS (\#TL1006, Himedia), 2-NBDG (Invitrogen: Cat no. 13195), Metformin (\#PHR 1084, Sigma), Acarbose (\#A8980, Sigma), Anti-Mouse Glut4 -Alexa Fluor 488 Antibody (\#NBPI-49533F, Novus Biologicals)), MTT Reagent (\# 4060,Himedia), DMSO (\#PHR1309,Sigma), FACS Calibur (BD-Biosciences, USA), Microplate reader(\#EC800,Biotek).

\section{Collection and preparation of Artabotrys} suaveolens plant extract

Artabotrys suaveolens was collected from the evergreen forests of Nilgiri in the Western Ghats, India and identified. The plant is also geographically distributed in Myanmar, Thailand, Malaysia, Indonesia and Philippines (Fig. 1).

A. suaveolens leaves were washed, shadedried and grounded into fine powder using mortar and pestle. The powder was mixed with methanol such that $20 \mathrm{~g}$ of the powder was mixed with 100 $\mathrm{mL}$ of methanol and was extracted using Soxhlet extraction and was filtered using a Filtermann
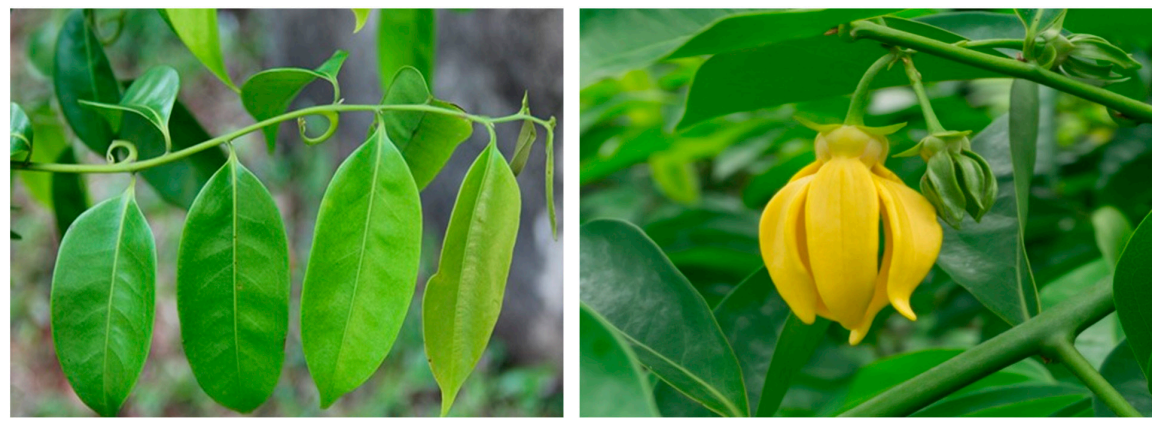

Fig. 1. Artabotrys suaveolens is a scrambling or climbing, evergreen shrub 
(125 $\mathrm{mm}$ ) filter paper. The extract was then concentrated and dried using a rotary evaporator. Cell culture

3T3-L1 (Mouse embryonic fibroblast) cell line was procured from NCCS, Pune. The cells were cultured in DMEM High Glucose supplemented with $10 \%$ FBS, 10,000 units of Penicillin G, 10000 $\mu \mathrm{g} / \mathrm{mL}$ Streptomycin, and $10 \mathrm{mM} \mathrm{HEPES}$. The cells were maintained at $37^{\circ} \mathrm{C}$ and $5 \% \mathrm{CO}_{2}$ incubator. The cells were passaged when they were $80-90 \%$ confluent.

\section{Cytotoxicity Assay}

The cytotoxic effect of AS extract on 3T3L1 cells was analysed using the MTT assay. Briefly, 3T3-L1 cells were seeded at an initial density of $20 * 10^{4}$ cells per well/200 $\mu \mathrm{L}$ in a 96 well plate and incubated overnight at $37^{\circ} \mathrm{C}$ with $5 \% \mathrm{CO}_{2}$. The cells were then treated with different concentrations ( 25 to $400 \mu \mathrm{g} / \mathrm{mL}$ ) of AS extract and was incubated for $24 \mathrm{~h}$ at $37^{\circ} \mathrm{C}$ with $5 \% \mathrm{CO}_{2}$. Post-treatment, $200 \mu \mathrm{L}$ of MTT reagent $(0.5 \mathrm{mg} / \mathrm{mL})$ was added to the cells. The 3T3-L1 cells were incubated for $2 \mathrm{~h}$ at $37^{\circ} \mathrm{C}$ and the crystals were dissolved by $20 \mu \mathrm{L}$ of DMSO. Absorbance at $570 \mathrm{~nm}$ was obtained using the microplate reader. Percentage viability of cells were calculated using the formula: \% cell viability $=($ Mean OD of test at $570 \mathrm{~nm} /$ Mean OD of Untreated cells at $570 \mathrm{~nm}) \times 100$

\section{Glucose uptake assay}

Glucose uptake assay was performed according to a previously described protocol ${ }^{12}$. 3T3-L1 cells were seeded at an initial density of

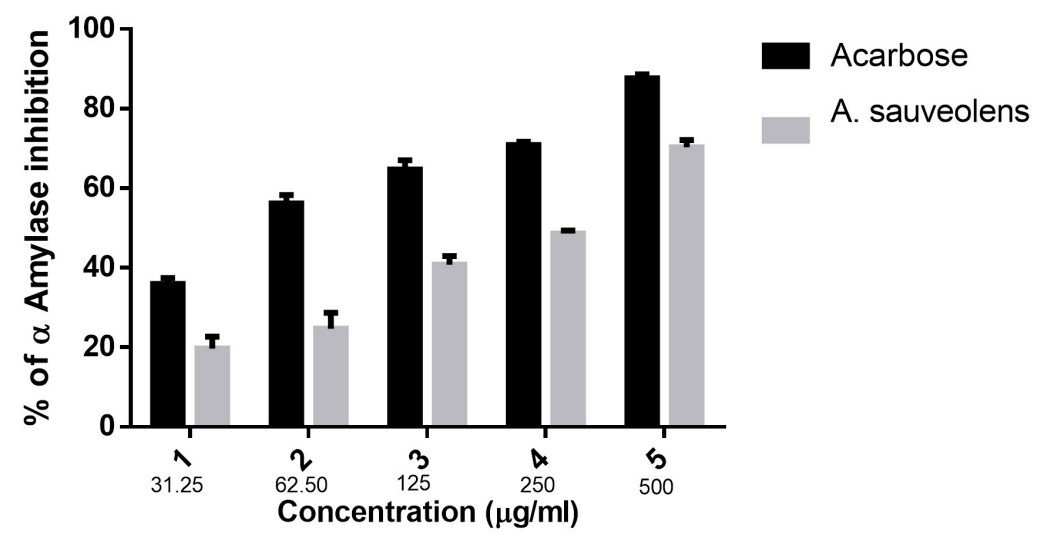

Fig. 2. Inhibition percentage of $\alpha$-amylase against at different concentrations of Acarbose and A. suaveolens; the IC50 value of the Acarbose and the extract were $49.19 \pm 8.1 \mu \mathrm{g} / \mathrm{mL}$ and $282.32 \pm 8.7 \mu \mathrm{g} / \mathrm{mL}$, respectively. Values are presented as mean \pm SD.

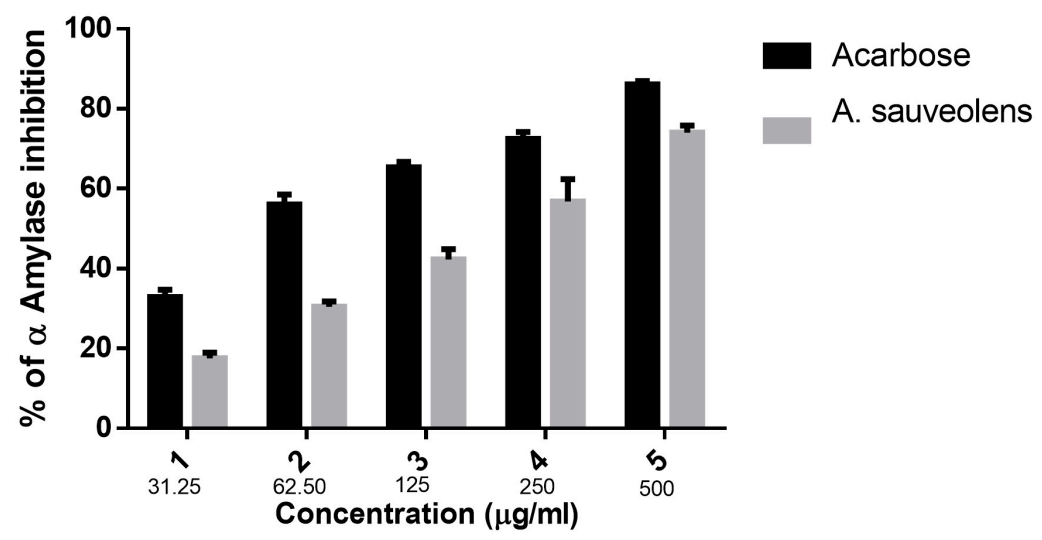

Fig. 3. Inhibition percentage of $\alpha$-Glucosidase at different concentrations of $A$. suaveolens and Acarbose; Values are presented as mean \pm SD. 
$2 * 10^{5}$ cells/well $/ 2 \mathrm{~mL}$ medium. The spent medium was aspirated, and the cells were washed with D-PBS. The cells were then treated with the extract $(100 \mu \mathrm{g} / \mathrm{mL})$ or Metformin $(100 \mu \mathrm{M})$, prepared in glucose-free DMEM, for $2 \mathrm{~h}$. To this, $100 \mu \mathrm{M}$ of $2-\mathrm{NBDG}$ was added. The cells were then trypsinized and the pellet was resuspended in 0.5 $\mathrm{mL}$ of D-PBS. Cellular uptake of the glucose analog, 2-NBDG was evaluated using Flow cytometry (BD FACS Calibur) and the data was analysed using Cell Quest Pro software.

\section{GLUT4 Expression studies}

The translocation of GLUT4 to the cytoplasmic membrane was analysed using flow cytometry $^{13}$. A 3T3-L1 cell were seeded at a density of $2 \times 105$ cells / well in a 6-well plate and was cultured overnight. The cells were then washed with D-PBS and were treated with the extract $(100 \mu \mathrm{g} / \mathrm{mL})$ or Metformin $(100 \mu \mathrm{M})$ for $24 \mathrm{~h}$. Post treatment, cells were trypsinized and the pellet

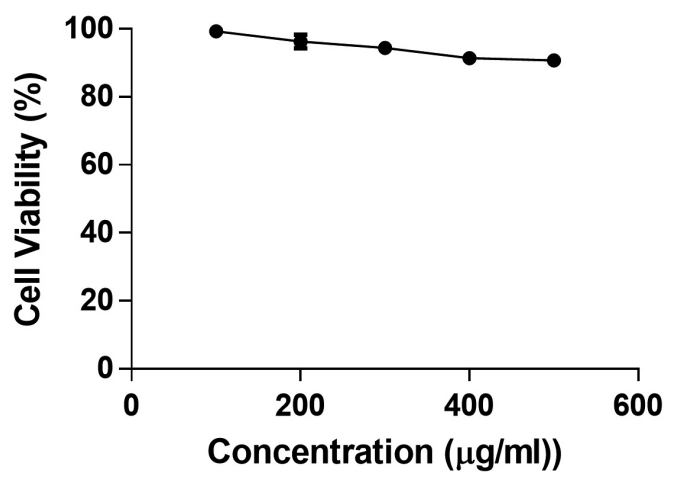

Fig. 4. The effect of $A$. suaveolens on 3T3-L1 cell line viability was analysed by MTT assay and the test compound didn't show high toxicity and IC50 couldn't be identified at given concentrations. was resuspended in $0.5 \mathrm{~mL} D$-PBS. The cells were incubated with Anti-Mouse Glut4-Alexa Fluor 488 antibody (\#NBPI-49533F, Novus Biologicals) for 30 mins in the dark and unbound antibodies were washed with DPBS. FL1 channel of FACS Calibur was used to determine GLUT4 expression. Cell Quest Pro software was used for data analysis.

Inhibition of $\alpha$-Amylase Activity

The $\alpha$-Amylase inhibition assay was performed for different concentrations of the extract $(31.25$ to $500 \mu \mathrm{g} / \mathrm{mL})$ according to a previously described method with slight modifications ${ }^{14}$. Equal volumes of $\alpha$-amylase and the mentioned concentration of the extract $(100 \mu \mathrm{L})$ were mixed and was incubated at $37^{\circ} \mathrm{C}$ for $10 \mathrm{~min}$ in microtubes. The reaction mixture was mixed with $100 \mu \mathrm{L}$ of $1 \%$ soluble starch for $30 \mathrm{~min}$ and was incubated at $37^{\circ} \mathrm{C}$. The reaction was arrested using $200 \mu \mathrm{L}$ of dinitrosalicylic acid at $100^{\circ} \mathrm{C}$ for $5 \mathrm{~min}$. From this mixture, $50 \mu \mathrm{L}$ of the mixture was transferred to 96-well microplate was further diluted with $200 \mu \mathrm{L}$ of distilled water in each well. Acarbose was used as positive control. Absorbance was measured at $540 \mathrm{~nm}$ using microplate reader (\#EC800, Biotek). The inhibitory activity of the extract was calculated by the following formula: \% inhibition = (Mean OD of Untreated Control - mean OD of test samples / Mean OD of Untreated Control) $\times 100$

Inhibition of $\alpha$-Glucosidase activity

The $\alpha$-glucosidase inhibition assay was performed with various concentrations of the extract $(31.25$ to $500 \mu \mathrm{g} / \mathrm{mL}$ ) according to a previously described method with slight modifications (15). $600 \mu \mathrm{L}$ of potassium phosphate buffer, and $25 \mu \mathrm{L}$ of enzyme ( $\alpha$-glucosidase, 1.2 $\mathrm{EU} / \mathrm{ml}$ ) were mixed with $100 \mu \mathrm{L}$ of test samples.
A)

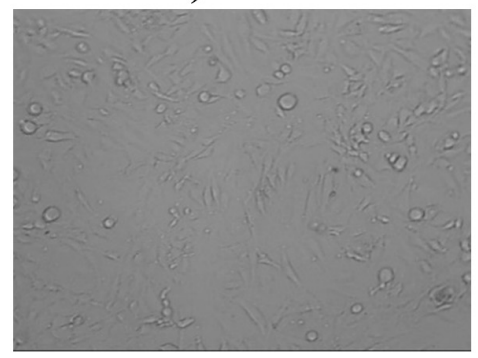

Fig. 5. Inverted light microscopy images of 3T3 L1 cell line after exposure to A. suaveolens, and Metformin. From ' $A$ ' to ' $C$ ' where A) control B) Standard Metformin drug and C) $400 \mu g$ concentration of $A$. suaveolens extract. 
The reaction mixture was incubated for $15 \mathrm{~min}$ at $37^{\circ} \mathrm{C}$. After this, $25 \mu \mathrm{L}$ of PNPG was added to the reaction mixture and was incubated for $15 \mathrm{~min}$ at $37^{\circ} \mathrm{C}$. The reaction was then arrested with $750 \mu \mathrm{L}$ of $\mathrm{Na}_{2} \mathrm{CO}_{3}$. The absorbance was measured at $405 \mathrm{~nm}$ by using a micro-plate reader (\#EC800, Biotek). The activity of the test sample was calculated by the following formula. Acarbose was used as positive control: \% Inhibition = (Mean OD of Untreated Control - mean OD of test samples / Mean OD of Untreated Control) $\times 100$

Table 1. Inhibition of $\alpha$-amylase enzyme activity by $A$. suaveolens extract

\begin{tabular}{lccc}
\hline Sample & $\begin{array}{c}\text { Concen. } \\
(\mu \mathrm{g} / \mathrm{mL})\end{array}$ & $\begin{array}{c}\text { \% inhibition of } \\
\text { enzyme activity }\end{array}$ & $\begin{array}{c}\mathrm{IC} 50 \\
(\mu \mathrm{g} / \mathrm{mL})\end{array}$ \\
\hline Acarbose & 31.25 & $35.99 \pm 1.44$ & \\
& 62.50 & $56.22 \pm 2.05$ & \\
& 125.00 & $64.70 \pm 2.3$ & $49.19 \pm 8.1$ \\
& 250.00 & $70.84 \pm 0.89$ & \\
A. & 500.00 & $87.65 \pm 0.96$ & \\
suaveolens & 31.25 & $19.73 \pm 3.00$ & \\
extract & 62.50 & $24.71 \pm 3.97$ & \\
& 125.00 & $40.75 \pm 2.18$ & $282.32 \pm 8.7$ \\
& 250.00 & $48.63 \pm 0.73$ & \\
\hline & 500.00 & $70.29 \pm 1.81$ & \\
\hline
\end{tabular}

\section{Statistical Analysis}

The experiments were conducted in triplicate $(n=3)$ and the results were expressed as mean \pm SD. Graph-Pad prism 5 was used for statistical and linear regression analysis.

\section{RESULTS}

\section{Inhibition of $\alpha$-Amylase Activity}

The percentage inhibition of $\alpha$-amylase activity by the plant extract was estimated with

Table 2. Inhibition of $\alpha$-Glucosidase enzyme activity by $A$. suaveolens extract

\begin{tabular}{lccc}
\hline Sample & $\begin{array}{c}\text { Concen } \\
(\mu \mathrm{g} / \mathrm{mL})\end{array}$ & $\begin{array}{c}\text { \% inhibition of } \\
\text { enzyme activity }\end{array}$ & $\begin{array}{c}\mathrm{IC} 50 \\
(\mu \mathrm{g} / \mathrm{mL})\end{array}$ \\
\hline Acarbose & 31.25 & $32.83 \pm 1.91$ & \\
& 62.50 & $56.07 \pm 2.42$ & \\
& 125.00 & $65.39 \pm 1.27$ & $55.84 \pm 6.42$ \\
& 250.00 & $72.49 \pm 1.72$ & \\
A. & 500.00 & $86.15 \pm 0.78$ & \\
suaveolens & 31.25 & $17.54 \pm 1.41$ & \\
extract & 62.50 & $30.45 \pm 1.37$ & \\
& 125.00 & $42.32 \pm 2.56$ & $235.46 \pm 18.55$ \\
& 250.00 & $56.79 \pm 5.54$ & \\
\hline
\end{tabular}

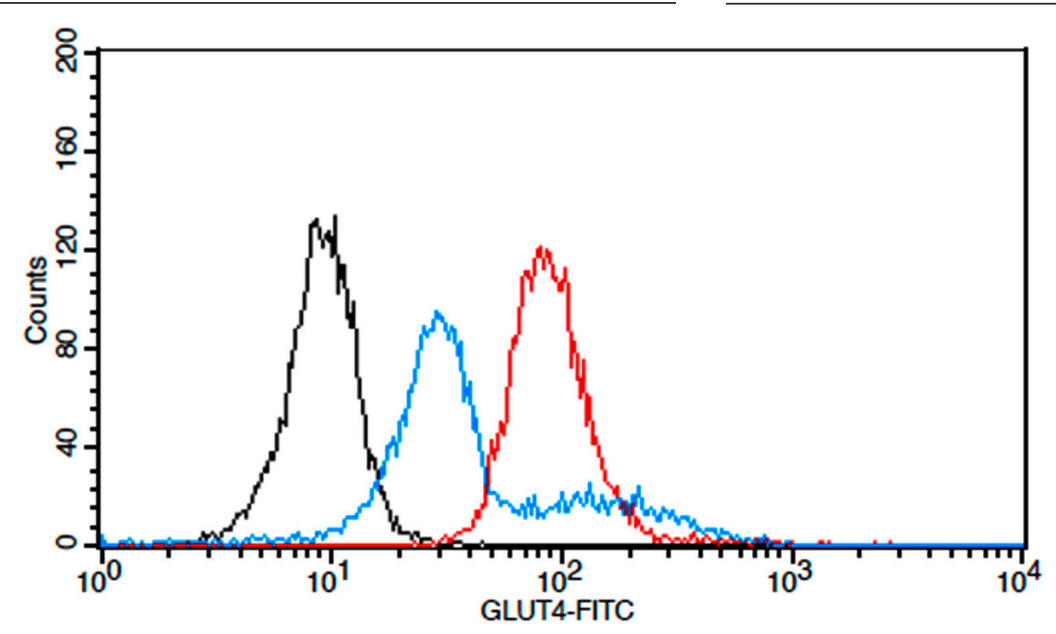

\begin{tabular}{llll} 
Key & Name & Parameter & Gate \\
\hline- & 3T3L1-CELL CONTROL & FL1-H & G1 \\
& 3T3L1-STD CONTROL & FL1-H & G1 \\
& 3T3L1-SAMPLE AS & FL1-H & G1
\end{tabular}

Fig. 6. Overlaid expression of GLUT4 in untreated 3T3L1 cells (black colour line) \& standard drug treated cells (metformin 100um) (red colour line) and test compound treated cells (cyan colour line). 
Acarbose as the positive control. A. suaveolens extract exhibited $19.73 \%$ inhibition in $\alpha$-amylase activity at $31.25 \mu \mathrm{g} / \mathrm{mL}$ concentration and $70.29 \%$ inhibition at $500 \mu \mathrm{g} / \mathrm{mL}$ concentration. The $\mathrm{IC}_{50}$ value was found to be $282.32 \pm 8.7 \mu \mathrm{g} / \mathrm{mL}$. Acarbose, the positive control, exhibited $35.99 \%$ inhibition of $\alpha$-amylase activity at $31.25 \mu \mathrm{g} / \mathrm{mL}$ and $87.65 \%$ inhibition at $500 \mu \mathrm{g} / \mathrm{mL}$ concentration. IC $\mathrm{C}_{50}$ value for Acarbose was found to be $49.19 \pm 8.1 \mu \mathrm{g}$ / $\mathrm{mL}$ shown in Table 1.

\section{Inhibition of $\alpha$-Glucosidase Activity}

The percentage inhibition of $\alpha$-glucosidase activity by AS extract was estimated with Acarbose as the positive control. AS extract exhibited, were $17.54 \%$ inhibition in $\alpha$-glucosidase activity at $31.25 \mu \mathrm{g} / \mathrm{mL}$ concentration and $74.06 \%$ inhibition at $500 \mu \mathrm{g} / \mathrm{mL}$ concentration. The $\mathrm{IC}_{50}$ value was found to be $235.46 \pm 18.55 \mu \mathrm{g} / \mathrm{mL}$. Acarbose, the positive control, exhibited $32.83 \%$ inhibition of $\alpha$-glucosidase activity at $31.25 \mu \mathrm{g} / \mathrm{mL}$ and $86.15 \%$ at $500 \mu \mathrm{g} / \mathrm{mL}$ concentration. $\mathrm{IC}_{50}$ value for Acarbose was found to be $55.84 \pm 6.42 \mu \mathrm{g} / \mathrm{mL}$ [Table 2; Fig. 3].

Cytotoxic effect of $A$. suaveolens on 3T3-L1 cell line

The cytotoxicity of $A$. suaveolens extract on 3T3-L1 cells was tested using MTT assay. Briefly, the cells were treated with different concentrations of the extract for $24 \mathrm{~h}$. The extract treated cells showed $99.30 \%$ viability at $25 \mu \mathrm{g} /$ $\mathrm{mL}$ and $91.07 \%$ at $400 \mu \mathrm{g} / \mathrm{mL}$, suggesting that the extract had no cytotoxic effect on 3T3L1 cells. The concentrations of the test compound and its corresponding percent cell viability has been tabulated in Table 3 and Fig. 4,5.

GLUT 4 translocation study in 3T3-L1 Cell line

Translocation of GLUT4 receptors from

Table 3. Cell viability effects of $A$. suaveolens extract in 3T3-L1 cell line

\begin{tabular}{lc}
\hline $\begin{array}{l}\text { Culture } \\
\text { conditions }\end{array}$ & $\begin{array}{c}\% \text { of } \\
\text { viability }\end{array}$ \\
\hline Control & $100.00 \pm 00$ \\
25 & $99.30 \pm 0.93$ \\
50 & $96.25 \pm 1.98$ \\
100 & $94.43 \pm 1.73$ \\
200 & $91.37 \pm 0.48$ \\
400 & $90.76 \pm 0.82$ \\
Metformin & $91.07 \pm 1.95$ \\
$(100 \mu \mathrm{M})$ &
\end{tabular}

cytoplasm to the cell membrane is crucial to glucose absorption. Cells were treated with $100 \mu \mathrm{g} /$ $\mathrm{mL}$ of AS extract for $24 \mathrm{~h}$ and GLUT4 expression was analyzed by Flow cytometry by probing with AntiMouse Glut4-Alexa Fluor 488 antibody (\#NBPI49533F, Novus Biologicals). Metformin was used as positive control at a concentration of $100 \mu \mathrm{M}$. The fluorescence intensity of cells treated with plant extract was significantly higher than the negative control [Fig. 6]. On treatment with the plant extract, $77.39 \%$ of cells showed GLUT4 expression and Metformin induced GLUT4 translocation in $99.96 \%$ of cells [Fig. 7].

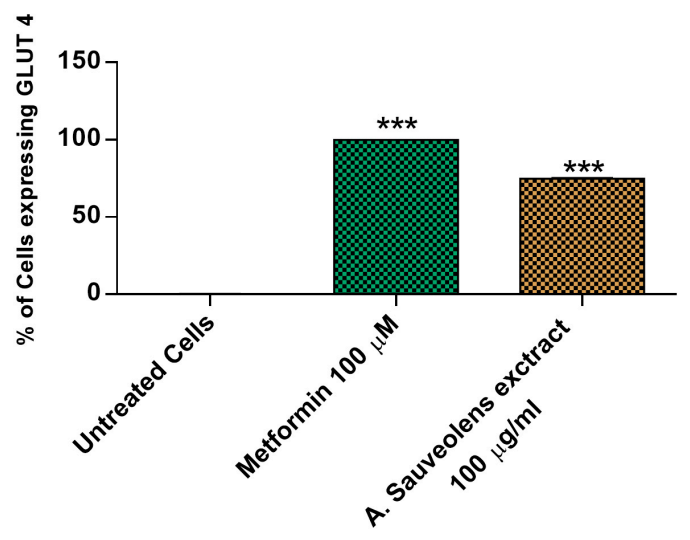

Fig. 7. GLUT Vs 3T3L1. The percentage of cells expressing GLUT4 comparison with Untreated, Metformin and $A$. suaveolens extract.

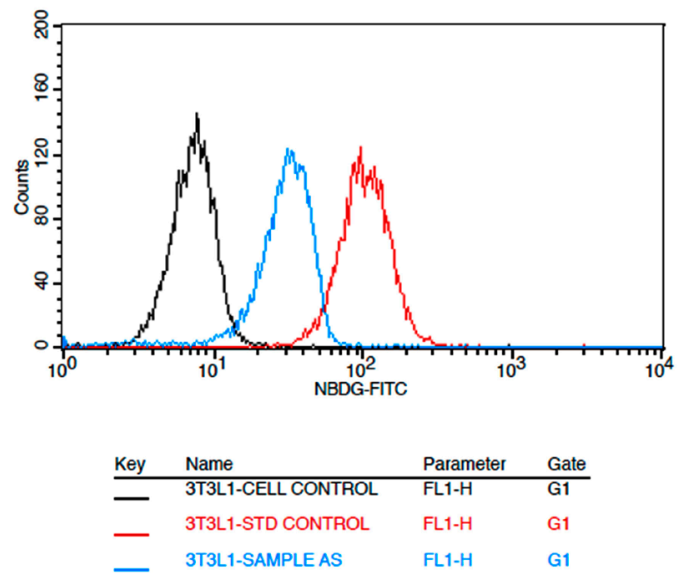

Fig. 8. Overlaid expression of given untreated 3T3L1 cells (black colour line) \& standard drug treated cells (metformin 100um) (red colour line) and test compound treated cells (cyan colour line) against the 2 -nbdg stain. 


\section{Glucose uptake Assay}

The effect of AS extract on glucose uptake was analyzed in 3T3-L1 cells using 2-NBDG, a fluorescent deoxyglucose analog. The 3T3-L1 cells were treated with $100 \mu \mathrm{g} / \mathrm{mL}$ of plant extract or with $100 \mu \mathrm{M}$ of Metformin. The cells treated with 2-NBDG alone was considered as negative control. The fluorescence intensity of cells treated with the extract was significantly high compared to the untreated cells (Fig. 8). Moreover, the percentage of cells that took up the 2-NBDG in the presence of plant extract was similar to the positive control, Metformin [Fig. 9].

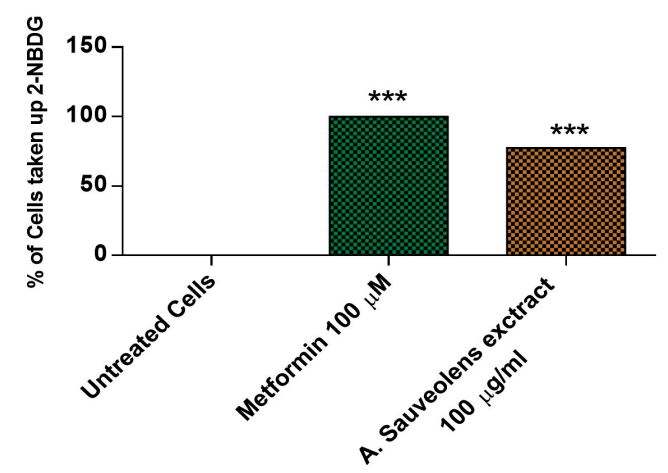

Fig. 9. The percentage of cells taken up 2-NBDG when treated with Metformin and test compound. Untreated cells are considered as negative control.

\section{DISCUSSION}

Diabetes mellitus has been a major cause of morbidity and mortality worldwide, with an estimated 382 million adult patients and 5.1 million deaths in 2013. Several studies have used multiple approaches to tackle DM. Amongst these inhibiting the enzymes that facilitate the absorption and metabolism of carbohydrates has been one approach. The important enzymes that are involved in glucose absorption from the gut are the pancreatic $\alpha$-amylase enzyme and $\alpha$-glucosidase enzyme. Inhibiting these enzymes reduces the absorption of glucose from the gut and thereby control the postprandial blood sugar levels ${ }^{16,17}$. The antidiabetic drugs, that are available in the market specifically inhibit the activity of these enzymes include Miglitol, Voglibose and Acarbose. However, long-term use of these drugs has several effects including flatulence and abdominal bloating ${ }^{18}$. Using natural compounds, which are extracted from medicinal plants, may not exert such effects ${ }^{19}$ and therefore play a vital role in treating ailments like Diabetes ${ }^{16,17,20,21}$.

The species of Artabotrys is a traditionally used plant species for different clinical conditions such as, cholera, scrofula, enlarged spleen and malaria. In the presented study, we evaluated the antidiabetic properties of methanolic extract of $A$. suaveolens leaves. Our results suggest that methanolic extract of $A$. suaveolens effectively inhibits the activities of $\alpha$-amylase and $\alpha$-glucosidase enzymes. These effects were determined using Acarbose as the standard drug. Additionally the cytotoxic effects of $A$. suaveolens have been tested on 3T3-L1 cells, the findings of the study reveals that $A$. suaveolens did not show any cytotoxicity on these cells. These findings are consistent with the earlier reports on the effect of natural compounds in inhibiting the enzyme activities of $\alpha$-amylase and $\alpha$-glucosidase enzymes $^{22-24}$.

\section{CONCLUSION}

In conclusion, AS extract significantly inhibited $\alpha$-amylase and $\alpha$-glucosidase enzyme activities with similar efficiency as the control, Acarbose. Glucose uptake and GLUT4 expression profile of 3T3-L1 cells treated with AS extract were also enhanced. Further, AS extract had no cytotoxic effects. These data suggest that methanolic extract of $A$. suaveolens has strong anti-diabetic properties and could possibly serve as a nutraceutical in treating Diabetes Mellitus. However, further studies must be carried out to establish these findings by identifying the specific modes or action and the specific constituents that drive these mechanisms.

\section{ACKNOWLEDGMENTS}

We would like to express our heartfelt thanks to the Stellixir Biotech Pvt. Ltd. for the support extended.

\section{CONFLICT OF INTEREST}

The authors declare that there is no conflict of interest.

\section{FUNDING}

None. 


\section{AUTHORS' CONTRIBUTION}

All authors listed have made substantial, direct and intellectual contribution to the work, and approved for publication

\section{DATA AVAILABILITY}

All datasets generated or analyzed during this study are included in the manuscript.

\section{ETHICS STATEMENT}

This article does not contain any studies with human participants or animals performed by any of the authors.

\section{REFERENCES}

1. Grover JK, Yadav S and Vats V. Medicinal plants of India with antidiabetic potential. J. Ethnopharmacol., 2002; 81: 81-100. https://doi.org/10.1016/S03788741(02)00059-4

2. Hashim A, Salman KM. and Ahmad S. Alleviation of Hyperglycemia and Hyperlipidemia by Phyllanthus virgatus Forst Extract and its Partially Purified Fraction in Streptozotocin Induced Diabetic Rats. EXCLI Journal, 2014; 13: 809-24.

3. Kharroubi, Akram T and Hisham M Darwish. "Diabetes mellitus: The epidemic of the century" World Journal of Diabetes, 2015; 6(6): 850-67. https://doi. org/10.4239/wjd.v6.i6.850

4. Lebovitz HE. Alpha-glucosidase inhibitors as agents in the treatment of diabetes. Diabetes Reviews, 1998; 6: 132-145.

5. Lordan S, TJ Smyth, A Soler-Vila, C Stanton and RP Ross. "The $\alpha$-amylase and $\alpha$-glucosidase inhibitory effects of Irish seaweed extracts," Food Chemistry, 2013; 141(3): 2170-2176. https://doi.org/10.1016/j. foodchem.2013.04.123

6. Aguilar NO, Artabotrys R Br. ex Ker Gawl. In Van Valkenburg JLCH and Bunyapraphatsara N (eds.). Plant resources of South-East Asia no. 12(2): medicinal and poisonous plants 2. Backhuys Publishers, 2001; 85-89.

7. Bryant NJ, Govers R, James DE. Regulated transport of the glucose transporter GLUT4. Nature Reviews Molecular Cell Biology, 2002; 3: 267-277. https://doi. org/10.1038/nrm782

8. Chakrabarti R and Rajagopalan R. Diabetes and insulin resistance associated disorders: disease and the therapy. Curr Sci., 2002; 83: 12.

9. Chen QC, ZhangWY, JinW, Lee IS, Min BS, Jung HJ, NaM, Lee S, Bae K. Flavonoids and isoflavonoids from sophorae flos improve glucose uptake in vitro. Planta Med., 2010; 76: 79-81. https://doi. org/10.1055/s-0029-1185944

10. Couvreur TP, Maas PJM, Meinke S et al., Keys to the genera of Annonaceae. Bot J Linn Soc., 2012; 169: 74-83. https://doi.org/10.1111/j.10958339.2012.01230.x
11. DiNicolantonio JJ, Bhutani J \& O’Keefe JH. Acarbose: safe and effective for lowering postprandial hyperglycaemia and improving cardiovascular outcomes. Open Heart, 2015; 2(1): e000327. https://doi.org/10.1136/ openhrt-2015-000327

12. Nesto R. CHD: a major burden in type 2 diabetes. Acta Diabetol., 2001; 38: 3-8. https://doi.org/10.1007/ s005920170002

13. Patel S, Gheewala N, Suthar A \& Shah A. In-vitro cytotoxicity activity of Solanum nigrum extract against Hela cell line and Vero cell line. International Journal of Pharmaceutical Science, 2009; 1: 38-46.

14. Sancheti S, Sancheti S and Seo SY. Chaenomeles sinensis: A potent $\alpha$-and $B$-glucosidase inhibitor. Am. J. Pharm. Toxicol., 2009; 4: 8-11. https://doi. org/10.3844/ajptsp.2009.8.11

15. Mogale MA, Lebelo SL, Thovhogi N, de Freitas AN, Shai LJ. $\alpha$-amylase and $\alpha$-glucosidase inhibitory effects of Sclerocarya birrea [ A.Rich. Hochst] subspecies caffra (sond) Kokwaro (Anacardiaceae) stem-bark extracts. African Journal of Botany, 2011; 15033-15039. https:// doi.org/10.5897/AJB11.1408

16. Tiwari BK, Pandey KB, Abidi AB and Rizvi SI. Therapeutic potential of Indian medicinal plants in diabetic condition. Ann. Phytomed., 2013; 2(1): 37-43.

17. Kuppusamy A, Muthusamy U, Andichetiar S, Thirumalaisamy, S Varadharajan, K Ramasamy, S Ramanathan. "In vitro ( $\alpha$-glucosidase and $\alpha$-amylase inhibition) and in vivo antidiabetic property of phytic acid (IP6) in streptozotocin-nicotinamideinduced type 2 diabetes mellitus (NIDDM) in rats," Journal of Complementary and Integrative Medicine, 2011; 8(1): article 9. https://doi.org/10.2202/1553-3840.1483

18. Gupta PD, Amartya D. Diabetes Mellitus and its herbal treatment. International Journal of Research in Pharmaceutical and Biomedical Sciences, 2012; 3(2): 706-712.

19. Rana CS, Radha Ballabha, Tiwari JK and Dangwal LR. An ethnobotanical study of the plant resources in the Nanda Devi Biosphere Reserve (a world heritage site), Uttarakhand, India. The J. of Ethnobio. and $T$ rad. Med., 2013b; 120: 591-601.

20. Rana CS, Tiwari JK, Dangwal LR and Gairola S. Faith herbal healer knowledge document of Nanda Devi Biosphere Reserve, Uttarakhand, India. Ind. Jour. of Trad. Know., 2013a; 12(2): 208- 214.

21. Poretsky L. Principles of diabetes mellitus (2nd ed.). New York: Springer, 2009; 3: ISBN 978-0-387-09840-1.

22. Scott $\sqcup$, Spencer CM. Miglitol: A review of its therapeutic potential in type 2 diabetes mellitus. Drugs, 2000; 59: 521-549. https://doi.org/10.2165/00003495200059030-00012

23. Bischoff H. Pharmacology of alpha-glucosidase inhibition. European Journal of Clinical Investigation, 1994; 24: 3-10.

24. Shepherd PR1, Withers DJ, Siddle K. Phosphoinositide 3-kinase: the key switch mechanism in insulin signalling. Biochem J., 1998; 333(3): 471-90. https:// doi.org/10.1042/bj3330471 